\title{
PERBANDINGAN ANTARA UNWEIGHTED LEAST SQUARES (ULS) DAN PARTIAL LEAST SQUARES (PLS) DALAM PEMODELAN PERSAMAAN STRUKTURAL (STUDI KASUS MODEL ANALISIS PRESTASI BELAJAR MAHASISWA TAHUN PERTAMA PROGRAM STUDI SI MATEMATIKA FMIPA-INSTUTUT PERTANIAN BOGOR)
}

\author{
Muhammad Amin Paris
}

\begin{abstract}
Abstrak
Structural Equation Modeling (SEM) is one of multivariate techniques that can estimates a series of interrelated dependence relationships from a number of endogenous and exogenous variables, as well as latent (unobserved) variables simultaneously. Estimation of Parameter methods that is often applied in SEM are Maximum Likelihood (ML), Weighted Least Squares (WLS), Unweighted Least Squares (ULS), Generalized Least Squares (GLS) and Partial Least Squares (PLS). This research aims to compare ULS method and PLS method in estimating parameter model of achievement of student learning in first year undergraduate Mathematics students, FMIPA, Bogor Agricultural University (IPB). This research use secondary and primary data which amounts to 112. The result of this research indicates that ULS method is more accurate than PLS methods. The analysis done with ULS method shows that motivation, capability and environmental had an effect to achievement of student learning.
\end{abstract}

Kata Kunci: SEM, ULS, PLS.

\section{Pendahuluan}

Hubungan sebab akibat (kausal) antar peubah dalam pendidikan di samping ada yang sederhana terdapat juga yang rumit. Hubungan kausal yang sederhana adalah hubungan kausal yang langsung; sedangkan hubungan kausal yang rumit adalah hubungan kausal yang bukan hanya langsung tetapi juga tidak langsung. Sebagai contoh, pengaruh peubahpeubah input dan proses pendidikan terhadap output pendidikan bukan hanya langsung tetapi juga tidak langsung melalui peubah-peubah lain dalam input dan proses pendidikan. Selain itu, banyak peubah dalam 
pendidikan yang tidak dapat diukur secara langsung (observed variable) melainkan berbentuk peubah laten (latent variable) yang harus dikonstruksi oleh peubah-peubah lain yang dapat diukur. Sebagai contoh, peubah kualitas guru (KG) tidak dapat diukur secara langsung, melainkan ia harus dikonstruksi dengan menggunakan peubah-peubah tingkat pendidikan, pengalaman mengajar, dan penguasaan materi ajarnya. Oleh karena itu, untuk menganalisis hubungan kausal dalam pendidikan yang bersifat struktural ini dibutuhkan metode analisis yang memperhitungkan sifat-sifat hubungan tersebut. $\mathrm{KG}$ dari contoh di atas disebut peubah tak teramati (laten) dan tiga peubah lainnya disebut peubah indikator bagi KG.

Menurut Bollen (1989), salah satu metode yang dapat digunakan untuk menganalisis hubungan kausal seperti dibahas di atas adalah Model Persamaan Struktural (MPS) atau Structural Equation Modeling (SEM). MPS mencakup model pengukuran dan model struktural. Model pengukuran menspesifikasikan hubungan antara peubah laten dengan indikator yang digunakan untuk mengkonstruksinya. Sedangkan model struktural menspesifikasikan hubungan sebab akibat antar peubah laten.

Adapun metode pendugaan parameter yang sering digunakan dalam pemodelan persamaan struktural adalah Maximum Likelihood (ML), Weighted Least Squares (WLS), Unweighted Least Squares (ULS), Generalized Least Squares (GLS) dan Partial Least Squares (PLS). Masingmasing metode tersebut mempunyai kriteria sendiri dalam proses pendugaannya, misalnya pada metode ULS dan PLS dalam proses pendugaan parameter MPS mempunyai perbedaan dan kesamaan. Perbedaan antara kedua metode tersebut dalam hal spesifikasi model, identifikasi, dan uji kelayakan. Sedangkan kesamaannya adalah tidak memerlukan asumsi sebaran (distribution-free) dari peubah pengamatan.

Adanya perbedaan dan kesamaan antara kedua metode inilah menarik kiranya dikaji secara empirik perbandingan antara hasil pendugaan parameter menggunakan metode ULS dan PLS dalam pemodelan persamaan struktural (MPS). 
Perbandingan Antara Unweighted Least Squares (UILS) Dan Partial Least Squares (PLS) Dalam Pemodelan Persamaan Struktural (Studi Kasus Model Analisis Prestasi Belajar Mahasiswa Tahun Pertama Program Studi S1 Matematika Fmipa-Instutut Pertanian Bogor)

Sesuai dengan permasalahan di atas maka tujuan penelitian ini adalah (1) menduga parameter model persamaan struktural (MPS) dengan metode ULS dan PLS; (2) membandingkan hasil dugaan parameter koefisien lintas model pengukuran, koefisien lintas model struktural, error model pengukuran dan tingkat keragaman $\left(R^{2}\right)$ yang dihasilkan oleh metode ULS dan PLS; dan (3) mengimplementasikan MPS dengan metode ULS dan PLS untuk menganalisis prestasi belajar mahasiswa tahun pertama Program Studi S1 Matematika FMIPA-IPB.

\section{Metode Penelitian}

Penelitian ini dilakukan dengan menggunakan data sekunder, yaitu data tentang prestasi belajar mahasiswa Tahun Pertama Program Studi S1 Matematika FMIPA-IPB dari tahun akademik 2005/2006 sampai dengan 2006/2007; dan data primer diperoleh melalui wawancara dengan mahasiswa dengan bantuan kuesioner terstruktur. Pengumpulan data primer melalui kuesioner pada 112 orang responden di Program Studi Matematika FMIPA-IPB.

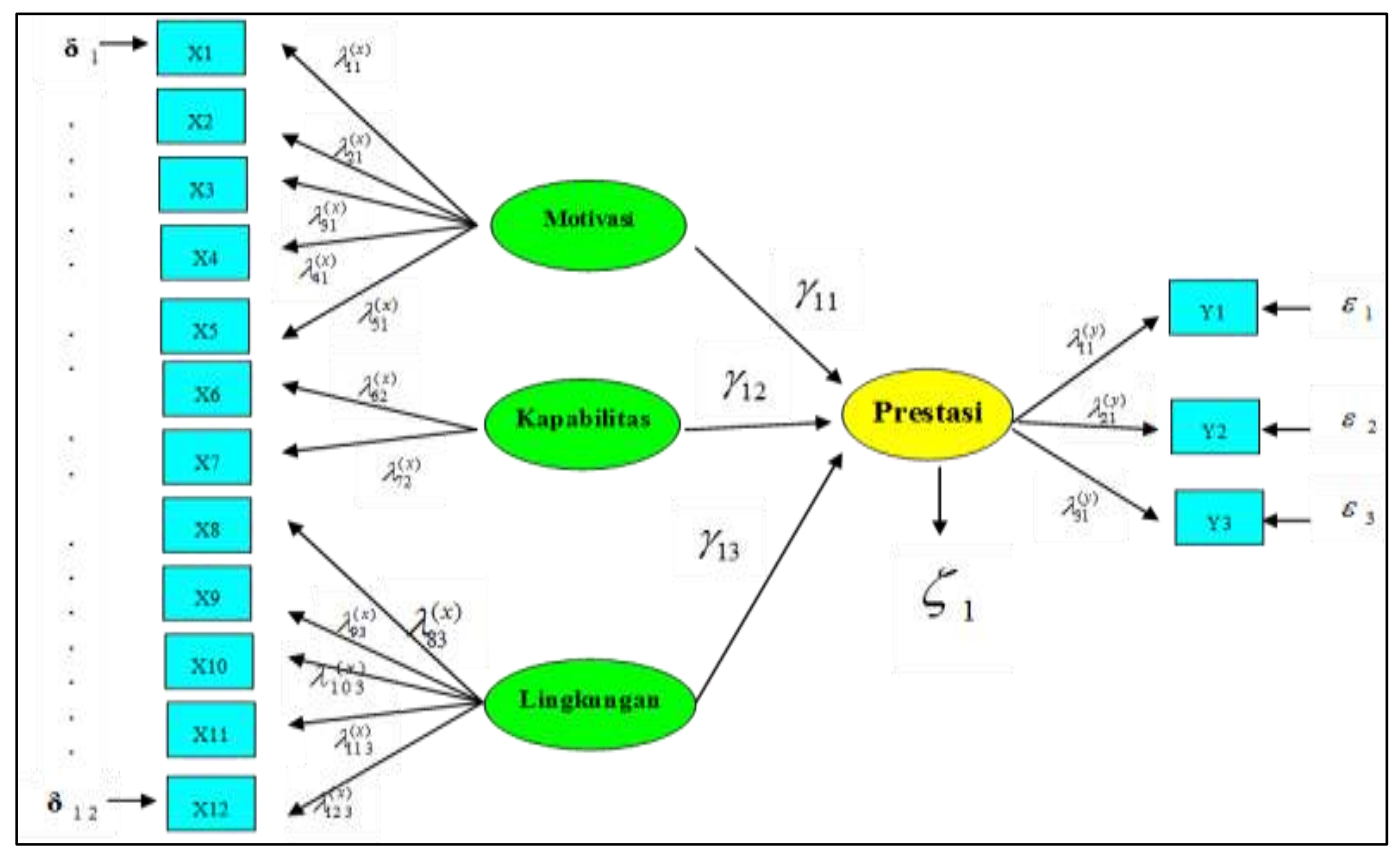

Gambar 1. Model Analisis Prestasi Belajar Mahasiswa Tahun Pertama Program Studi S1 Matematika FMIPA-IPB. 
Penjelasan peubah laten dan peubah penjelas (indikator) dari Gambar 1 dijelaskan pada Tabel 1 berikut.

Tabel 1. Peubah Laten dan Peubah Penjelas Model Persamaan Struktural Analisis Prestasi Belajar Mahasiswa Tahun Pertama Program Studi S1 Matematika FMIPA-IPB.

\begin{tabular}{|c|c|c|c|}
\hline No & \begin{tabular}{|c|}
$\begin{array}{c}\text { Peubah Laten } \\
\text { Eksogen }\end{array}$ \\
\end{tabular} & Peubah Penjelas & Simbol \\
\hline \multirow{5}{*}{1} & \multirow{5}{*}{ Motivasi } & Pemilihan kampus tempat belajar sekarang & $X_{1}$ \\
\hline & & Bidang studi sesuai dengan cita-cita & $X_{2}$ \\
\hline & & Kelompok belajar & $x_{3}$ \\
\hline & & Kunjungan ke perpustakaan & $X_{4}$ \\
\hline & & Cara belajar & $X_{5}$ \\
\hline \multirow{2}{*}{2} & \multirow{2}{*}{ Kapabilitas } & NEM SMA & $x_{6}$ \\
\hline & & Nilai rata-rata ijazah SMA & $X_{7}$ \\
\hline \multirow{5}{*}{3} & \multirow{5}{*}{ Lingkungan } & Situasi tempat tinggal & $X_{8}$ \\
\hline & & Fasilitas belajar di tempat tinggal & $X_{9}$ \\
\hline & & Waktu tempuh dari tempat tinggal ke kampus & $X_{10}$ \\
\hline & & Konsentrasi & $\mathrm{X}_{11}$ \\
\hline & & Sumber biaya hidup/kuliah & $X_{12}$ \\
\hline No & $\begin{array}{c}\text { Peubah Laten } \\
\text { Endogen }\end{array}$ & Peubah Penjelas & \\
\hline \multirow{3}{*}{1} & \multirow{3}{*}{ Prestasi } & Indeks prestasi kumulatif (IPK) & $\mathrm{Y}_{1}$ \\
\hline & & Nilai rata-rata MKDU & $Y_{2}$ \\
\hline & & Nilai rata-rata MKDK & $Y_{3}$ \\
\hline
\end{tabular}

Analisis data sampel dengan metode ULS menggunakan software LISREL 8.30 melalui tahapan sebagai berikut: (1) Merumuskan model; (2) membuat matriks input yaitu matriks korelasi dengan menggunakan paket program PRELIS; (3) menduga parameter-parameter model berdasarkan hasil matriks korelasi; (4) perhitungan nilai Construct Reliability dan Variance Extracted; (5) evaluasi kelayakan model yang telah dihasilkan berdasarkan uji kebaikan model: $\chi^{2}$, GFI, AGFI, RMSEA, RMSR.

Adapun pengolahan data sampel pada metode PLS menggunakan software LVPLS 1.8 melalui tahapan-tahapan sebagai berikut:

1. Merumuskan spesifikasi model PLS.

2. Menduga pembobot-pembobot, koefisien-koefisien lintas dan nilainilai peubah laten dengan menggunakan algoritma PLS untuk sidik 
Perbandingan Antara Unweighted Least Squares (UILS) Dan Partial Least Squares (PLS) Dalam Pemodelan Persamaan Struktural (Studi Kasus Model Analisis Prestasi Belajar Mahasiswa Tahun Pertama Program Studi S1 Matematika Fmipa-Instutut Pertanian Bogor)

lintas peubah laten, dengan tahap-tahap dan langkah-langkah yang diuraikan sebagai berikut:

Tahap1. Pendugaan iteratif dari pembobot-pembobot dan nilai-nilai peubah laten dimulai pada langkah \#4 dan selanjutnya langkah \#1 sampai langkah \#4 diulang sampai konvergen dengan batas kekonvergenan yang telah ditentukan.

\#1. Pembobotan model struktural

$$
v_{j i}= \begin{cases}\operatorname{sign} \operatorname{cov}\left(\eta_{j}, \eta_{i}\right) \text { jika } \eta_{j} \text { dan } \eta_{i} \text { berdekatan, } \\ 0 & \text { selainnya }\end{cases}
$$

\#2. Pendugaan model struktural

$$
\hat{\eta}_{j}=\sum_{i} v_{i j} \eta_{i}
$$

\#3. Pembobotan model pengukuran

$$
\begin{gathered}
y_{k}=\hat{w}_{k} \eta_{j}+e_{k} \quad \text { (outward) } \\
\hat{\eta}_{j}=\sum_{k} \hat{w}_{k} y_{k}+d_{j} \quad \text { (inward) }
\end{gathered}
$$

\#4. Pendugaan model pengukuran

$$
\eta_{j}=f_{i} \sum_{k} \hat{w}_{k} y_{k}
$$

Tahap 2. Pendugaan koefisien-koefisien lintas (Chin, 2000)

1. Menguji validitas kekonvergenan.

2. Menguji validitas diskriminan.

3. Menguji koefisien lintas model menggunakan teknik Jacknife.

4. Menguji kekuatan prediktif dengan statistik $Q^{2}$.

\section{Hasil dan Pembahasan}

Hasil Pendugaan Parameter Model dengan Metode ULS dan PLS diuraikan sebagai berikut:

\section{Hasil Pendugaan Parameter Model dengan Metode ULS}

Ringkasan hasil dugaan koefisien lintas model pengukuran dengan metode ULS pada model awal disajikan pada Tabel 2 berikut. 
Tabel 2. Hasil Pendugaan dan Pengujian Koefisien Lintas Model Pengukuran dengan Metode ULS.

\begin{tabular}{|c|c|c|c|c|}
\hline Peubah Laten & Peubah Penjelas & Nilai $\lambda$ & Nilai T & Error Variance \\
\hline \multirow{5}{*}{ Motivasi } & $X_{1}$ & 0.85 & $21.36 *$ & 0.27 \\
\hline & $X_{2}$ & 0.83 & $20.48 *$ & 0.31 \\
\hline & $X_{3}$ & 0.84 & $21.22 *$ & 0.29 \\
\hline & $X_{4}$ & 0.84 & $21.14 *$ & 0.30 \\
\hline & $X_{5}$ & 0.99 & $23.55 \%$ & 0.01 \\
\hline \multicolumn{5}{|c|}{ Construct Reliability $=0.94$, Variance Extracted $=0.76$} \\
\hline \multirow{2}{*}{ Kapabilitas } & $X_{6}$ & 0.84 & $17.23 *$ & 0.29 \\
\hline & $x_{7}$ & 0.96 & $19.45 *$ & 0.07 \\
\hline \multicolumn{5}{|c|}{ Construct Reliability $=0.90$, Variance Extracted $=0.82$} \\
\hline \multirow{5}{*}{ Lingkungan } & $X_{8}$ & 0.94 & $21.92 *$ & 0.11 \\
\hline & $X_{9}$ & 0.56 & $13.58 *$ & 0.69 \\
\hline & $X_{10}$ & 0.74 & $17.49 *$ & 0.45 \\
\hline & $X_{11}$ & 0.89 & $21.14 *$ & 0.21 \\
\hline & $X_{12}$ & 0.50 & $12.00 *$ & 0.75 \\
\hline \multicolumn{5}{|c|}{ Construct Reliability $=0.86$, Variance Extracted $=0.56$} \\
\hline \multirow{3}{*}{ Prestasi } & $Y_{1}$ & 0.94 & $11.15 *$ & 0.11 \\
\hline & $Y_{2}$ & 0.76 & $13.96 *$ & 0.43 \\
\hline & $Y_{3}$ & 0.79 & $14.08 \%$ & 0.37 \\
\hline
\end{tabular}

*Nilai T nyata pada $\alpha=0.05$

Berdasarkan Tabel 2 terlihat bahwa hasil dugaan parameter koefisien lintas model pengukuran yang dihasilkan metode ULS menunjukkan semua peubah penjelas (indikator) signifikan dalam mengukur atau merefleksikan peubah laten (semua nilai $\mathrm{T}$ hitung dalam Tabel 2 > nilai T kritis (T tabel) yaitu, 1.96). Nilai T tabel diambil dengan menggunakan ketentuan $\alpha=0.05$ dan degree of freedom sebesar $n-2$. Sedangkan nilai construct reliability dan variance extracted peubah laten motivasi, kapabilitas, lingkungan dan prestasi berturut-turut sudah berada diatas nilai yang direkomendasikan yaitu, 0.7 dan 0.5. Dengan demikian disimpulkan peubah penjelas reliabel (andal) dalam merefleksikan peubah latennya.

Sedangkan ringkasan hasil pendugaan koefisien lintas model struktural pada model awal disajikan pada Tabel 3 berikut. 
Perbandingan Antara Unweighted Least Squares (UILS) Dan Partial Least Squares (PLS) Dalam Pemodelan Persamaan Struktural (Studi Kasus Model Analisis Prestasi Belajar Mahasiswa Tahun Pertama Program Studi S1 Matematika Fmipa-Instutut Pertanian Bogor)

Tabel 3. Hasil Pendugaan dan Pengujian Koefisien Lintas Model Struktural dengan Metode ULS

\begin{tabular}{|ll|c|c|}
\hline \multicolumn{2}{|c|}{ Peubah Laten } & Koefisien Lintas & Nilai T \\
\hline Motivasi $\rightarrow$ & 0.42 & $3.37 *$ \\
\hline Kapabilitas $\rightarrow$ & Prestasi & 0.09 & $2.30 *$ \\
\hline Lingkungan $\rightarrow$ & Prestasi & 0.32 & $2.63 *$ \\
\hline
\end{tabular}

*Nilai T nyata pada $\alpha=0.05$

Hasil pendugaan koefisien lintas pada model struktural yang disajikan pada Tabel 3 menunjukkan bahwa peubah laten eksogen yaitu, motivasi, kapabilitas dan lingkungan berpengaruh nyata pada peubah laten eksogen (prestasi).

Uji kelayakan model awal dapat dilihat pada Tabel 4 berikut ini.

Tabel 4. Kriteria Kelayakan Model Dugaan Awal

\begin{tabular}{|c|c|c|}
\hline Kriteria & Nilai & Nilai ideal \\
\hline$\chi^{2}$ & 107.24 (nilai $\mathrm{P}=0.06450)$ & Nilai $\mathrm{P} \geq 0.05$ \\
\hline RMSEA & 0.050 & $\leq 0.08$ \\
\hline GFI & 0.99 & $\geq 0.90$ \\
\hline AGFI & 0.99 & $\geq 0.80$ \\
\hline RMSR & 0.044 & Relatif kecil \\
\hline
\end{tabular}

Hasil uji kelayakan model awal seperti tersaji pada Tabel 4 nilai $\chi^{2}$ sebesar 107.24 (nilai $\mathrm{P}=0.06450$ ) menunjukkan model awal layak mengepas data dengan baik. Sedangkan nilai uji kelayakan model yang lain yaitu, nilai RMSEA, GFI, AGFI dan RMSR juga sudah berada pada kriteria yang ideal. Nilai uji kelayakan model tersebut menunjukkan bahwa keadaan emperis data sesuai dengan model, berarti model sudah layak.

2. Hasil Pendugaan Parameter Model dengan Metode PLS. 
Ringkasan hasil dugaan parameter koefisien lintas model pengukuran dengan metode PLS pada model awal disajikan pada Tabel 5 berikut ini.

Tabel 5 Hasil Pendugaan dan Pengujian Koefisien Lintas Model Pengukuran dengan Metode PLS

\begin{tabular}{|c|c|c|c|c|}
\hline Peubah Laten & Peubah Penjelas & Nilai $\lambda$ & Nilai T & Residual (Error) \\
\hline \multirow{5}{*}{ Motivasi } & $X_{1}$ & 0.82 & $12.00 *$ & 0.33 \\
\hline & $X_{2}$ & 0.81 & $14.33 *$ & 0.34 \\
\hline & $X_{3}$ & 0.83 & 19.80* & 0.31 \\
\hline & $X_{4}$ & 0.82 & $17.49 *$ & 0.33 \\
\hline & $X_{5}$ & 0.92 & $33.30 *$ & 0.16 \\
\hline \multirow{2}{*}{ Kapabilitas } & $x_{6}$ & 0.82 & $17.16 *$ & 0.27 \\
\hline & $x_{7}$ & 0.90 & $26.51 *$ & 0.20 \\
\hline \multirow{5}{*}{ Lingkungan } & $X_{8}$ & 0.89 & $17.22 *$ & 0.21 \\
\hline & $X_{9}$ & 0.50 & $3.58 *$ & 0.75 \\
\hline & $X_{10}$ & 0.80 & $9.03 *$ & 0.36 \\
\hline & $X_{11}$ & 0.87 & $24.46 *$ & 0.24 \\
\hline & $X_{12}$ & 0.54 & $3.28 *$ & 0.77 \\
\hline \multirow{3}{*}{ Prestasi } & $Y_{1}$ & 0.91 & 29.59* & 0.14 \\
\hline & $Y_{2}$ & 0.74 & $18.84 *$ & 0.28 \\
\hline & $Y_{3}$ & 0.77 & $21.26 *$ & 0.40 \\
\hline
\end{tabular}

*Nilai T nyata pada $\alpha=0.05$

Hasil pendugaan koefisien lintas pada model pengukuran yang ditampilkan pada Tabel 5 memperlihatkan setiap peubah penjelas signifikan dalam mengukur atau merefleksikan peubah latennya. Sedangkan evaluasi terhadap kekuatan model pengukuran diuji dengan validitas kekonvergenan yaitu, menggunakan Composite Reliability $\left(\rho_{c}\right)$ dan Average Variance Extracted (AVE) untuk setiap peubah laten, yang disajikan pada Tabel 6 berikut ini.

Tabel 6. Composite Reliability $\left(\rho_{c}\right)$ dan Average Variance Extracted (AVE)

\begin{tabular}{|l|c|c|c|}
\hline Peubah Laten & $\rho_{c}$ & $A V E$ & $\sqrt{A V E}$ \\
\hline Motivasi & 0.92 & 0.71 & 0.84 \\
\hline
\end{tabular}


Perbandingan Antara Unweighted Least Squares (UILS) Dan Partial Least Squares (PLS) Dalam Pemodelan Persamaan Struktural (Studi Kasus Model Analisis Prestasi Belajar Mahasiswa Tahun Pertama Program Studi S1 Matematika Fmipa-Instutut Pertanian Bogor)

\begin{tabular}{|l|l|l|l|}
\hline Kapabilitas & 0.86 & 0.74 & 0.86 \\
\hline Lingkungan & 0.85 & 0.55 & 0.74 \\
\hline Prestasi & 0.88 & 0.66 & 0.81 \\
\hline
\end{tabular}

Nilai $\rho_{c}$ dari setiap peubah laten menunjukkan kesetabilan dan kekonsistenan dari pengukuran reliabilitas gabungan. Nilai $\rho_{c}$ yang berada pada kisaran 0.8 pada Tabel 6 mengindikasikan bahwa seluruh peubah laten memiliki nilai reliabilitas gabungan yang baik. Nilai AVE pada Tabel 6 lebih dari nilai yang direkomendasikan yaitu 0.5. Hal ini menunjukkan peubah laten motivasi, kapabilitas, lingkungan dan prestasi memperlihatkan keragaman dari peubah penjelas yang diakomodasi oleh peubah laten lebih besar dibandingkan dengan jumlah keragaman yang tidak dapat dijelaskan oleh peubah penjelas.

Sedangkan hasil dugaan koefisien lintas model struktural disajikan pada Tabel 7 berikut.

Tabel 7. Hasil Pendugaan dan Pengujian Koefisien Lintas Model Struktural dengan Metode PLS

\begin{tabular}{|c|c|c|c|c|}
\hline \multicolumn{3}{|c|}{ Peubah Laten } & Koefisien Lintas & Nilai T \\
\hline Motivasi & $\rightarrow$ & Prestasi & 0.39 & $2.72 *$ \\
\hline Kapabilitas & $\longrightarrow$ & Prestasi & 0.06 & $2.19 *$ \\
\hline Lingkungan & $\longrightarrow$ & Prestasi & 0.19 & $2.61 \%$ \\
\hline
\end{tabular}

*Nilai T nyata pada $\alpha=0.05$

Berdasarkan Tabel 7 seluruh peubah laten eksogen yaitu, motivasi, kapabilitas dan lingkungan berpengaruh nyata terhadap peubah laten endogen yaitu, prestasi. Untuk mengetahui kesesuaian pembeda dari peubah laten dapat digunakan uji validitas diskriminan yaitu, dengan cara membandingkan akar kuadrat AVE setiap peubah laten pada Tabel 6 dengan korelasi antar peubah laten yang disajikan pada Tabel 8 berikut ini.

Tabel 8. Korelasi Antar Peubah Laten 


\begin{tabular}{|c|c|c|c|}
\hline Peubah laten & Motivasi & Kapabilitas & Lingkungan \\
\hline Motivasi & 1 & & \\
\hline Kapabilitas & 0.70 & 1 & 1 \\
\hline Lingkungan & 0.68 & 0.67 & 0.72 \\
\hline Prestasi & 0.71 & 0.64 & \\
\hline
\end{tabular}

Berdasarkan Tabel 6 dan 8 nilai akar kuadrat AVE lebih dari semua koefisien korelasi antar peubah laten tiap blok, hal ini menunjukkan bahwa validitas diskriminan pada peubah laten cukup baik. Nilai $Q^{2}=0.53$ (Lampiran 2). menyatakan kekuatan pendugaan yang cukup relevan.

\section{Perbandingan Hasil Dugaan Parameter Metode ULS dan PLS}

1. Perbandingan Nilai Koefisien Lintas Model Pengukuran

Perbandingan hasil pendugaan parameter koefisien lintas model pengukuran yang dihasilkan metode ULS dan PLS dapat dilihat pada Gambar 3 berikut ini.

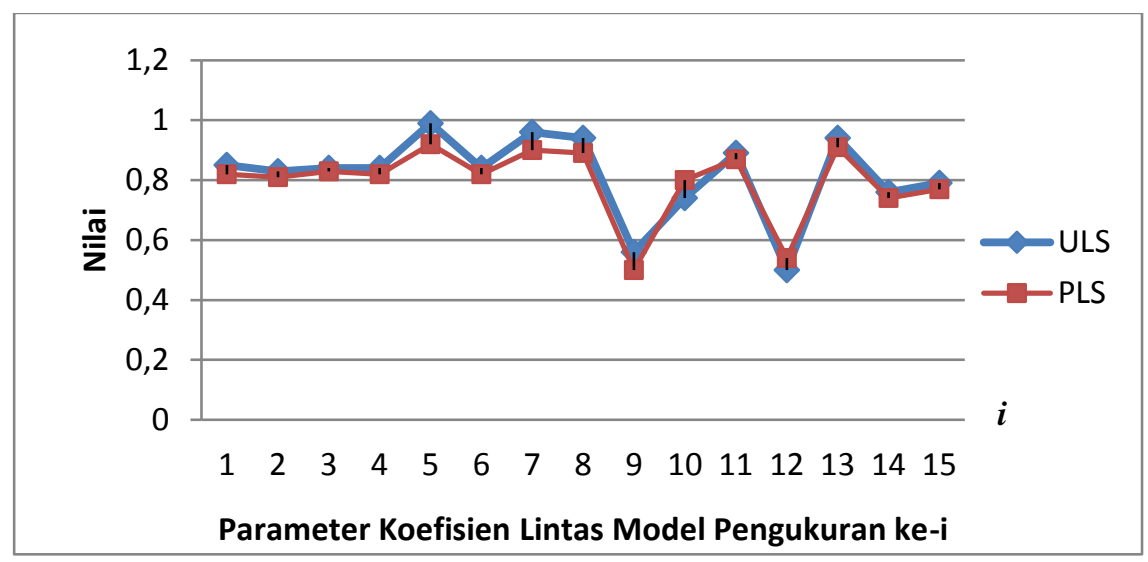

Gambar 3. Perbandingan Hasil Dugaan Parameter Koefisien Lintas Model Pengukuran yang Dihasilkan Metode ULS dan PLS

Berdasarkan Gambar 3 dapat dilihat secara umum bahwa nilai koefisien lintas model pengukuran yang dihasilkan metode ULS lebih besar dari nilai koefisien lintas model pengukuran yang dihasilkan metode PLS. Dengan demikian dapat disimpulkan nilai kofisen lintas yang dihasilkan 
Perbandingan Antara Unweighted Least Squares (UILS) Dan Partial Least Squares (PLS) Dalam Pemodelan Persamaan Struktural (Studi Kasus Model Analisis Prestasi Belajar Mahasiswa Tahun Pertama Program Studi S1 Matematika Fmipa-Instutut Pertanian Bogor)

metode ULS lebih besar daripada nilai koefisien lintas yang dihasilkan metode PLS.

2. Perbandingan Nilai Koefisien Lintas Model Struktural

Perbandingan hasil dugaan parameter koefisien lintas model struktural yang dihasilkan metode ULS dan PLS dapat dilihat pada Gambar 4 berikut ini.

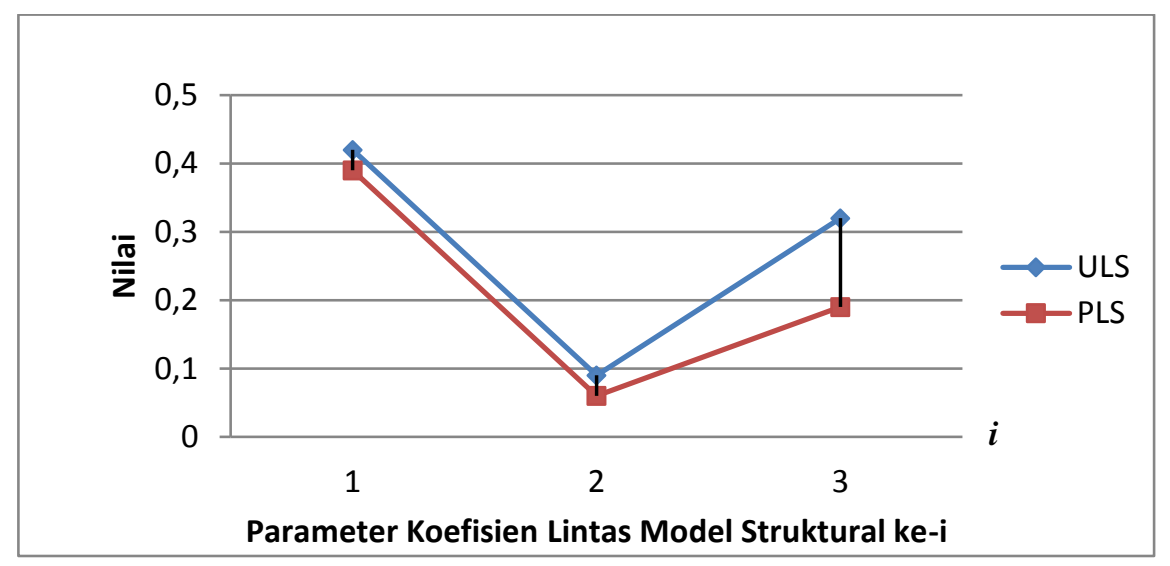

Gambar 4. Perbandingan Hasil Dugaan Parameter Koefisien Lintas Model Struktural yang Dihasilkan Metode ULS dan PLS

Berdasarkan Gambar 8 nilai koefisien lintas model sruktural yang dihasilkan metode ULS lebih dari nilai koefisien lintas model struktural yang dihasilkan metode PLS. Dengan demikian dapat disimpulkan nilai kofisien lintas yang dihasilkan metode ULS lebih besar daripada nilai koefisien lintas yang dihasilkan metode PLS.

\section{Perbandingan Error Model Pengukuran}

Perbandingan hasil dugaan parameter error model pengukuran yang dihasilkan metode ULS dan PLS dapat dilihat pada Gambar 5 berikut ini. 


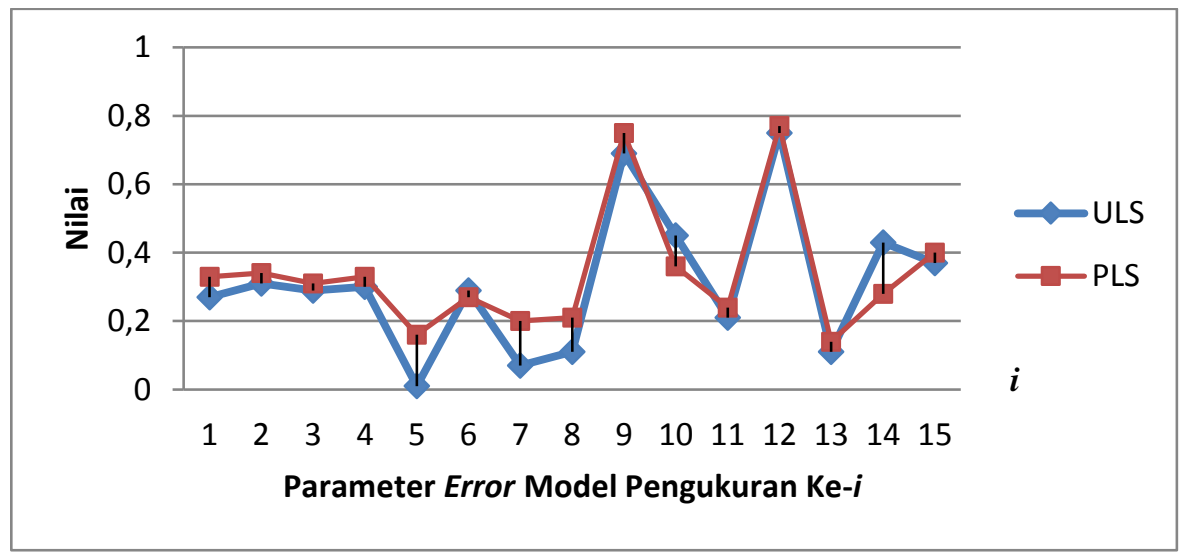

Gambar 5. Perbandingan Hasil Dugaan Parameter Error Model Pengukuran yang Dihasilkan Metode ULS dan PLS

Berdasarkan Gambar 5 terlihat secara umum bahwa nilai error pengukuran yang dihasilkan metode PLS lebih besar dari nilai error pengukuran yang dihasilkan metode ULS. Sebagaimana kita ketahui bahwa error dalam pengukuran diharapkan sekecil mungkin. Dengan demikian dapat disimpulkan bahwa error pengukuran yang dihasilkan metode ULS lebih kecil daripada error pengukuran yang dihasilkan metode PLS.

\section{Perbandingan Tingkat Keragaman $\left(R^{2}\right)$}

Nilai $R^{2}$ yang dihasilkan metode ULS dan PLS berturut-turut adalah sebesar 0.62 dan 0.57 . Hal ini berarti bahwa tingkat keragaman $\left(R^{2}\right)$ yang dihasilkan metode ULS lebih baik daripada yang dihasilkan metode PLS. Sehingga dapat disimpulkan bahwa metode ULS lebih tepat daripada metode PLS dalam menduga parameter model persamaan struktural.

\section{Analisis Prestasi Belajar Mahasiswa Tahun Pertama Program Studi S1 Matematika FMIPA-IPB.}

Untuk menganalisis prestasi belajar mahasiswa tahun pertama Program Studi S1 Matematika FMIPA-IPB digunakan metode ULS. Metode ini dipilih karena berdasarkan hasil perbandingan tingkat keragaman yang dihasilkan metode ULS lebih tepat digunakan daripada yang dihasilkan metode PLS. 
Perbandingan Antara Unweighted Least Squares (UILS) Dan Partial Least Squares (PLS) Dalam Pemodelan Persamaan Struktural (Studi Kasus Model Analisis Prestasi Belajar Mahasiswa Tahun Pertama Program Studi S1 Matematika Fmipa-Instutut Pertanian Bogor)

\section{Interpretasi Hasil Dugaan Parameter Koefisien Lintas Model Pengukuran}

a) Peubah motivasi dibangun oleh 5 indikator, yang paling dominan mengukur peubah laten motivasi adalah cara belajar $\left(X_{5}\right)$, dimana dalam perhitungan diperoleh angka sebesar 0.99. Sedangkan indikator terkecil yang mengukur motivasi adalah bidang studi sesuai dengan cita-cita $\left(X_{2}\right)$, yang diperoleh hasil perhitungan sebesar 0.83. Dapat disimpulkan bahwa indikator yang paling dominan mengukur motivasi mahasiswa adalah cara belajar $\left(X_{5}\right)$ mahasiswa tersebut.

b) Peubah kapabilitas dibangun oleh 2 indikator, yang paling dominan mengukur peubah kapabilitas adalah nilai rata-rata ijazah SMA $\left(X_{7}\right)$, dimana dalam perhitungan diperoleh angka sebesar 0.96. Sedangkan indikator terkecil yang mengukur kapabilitas adalah $\operatorname{NEM~SMA~}\left(\mathrm{X}_{6}\right)$ yang diproleh hasil perhitungan sebesar 0.84. Dengan demikian dapat disimpulkan baghwa indikator yang paling dominan mengukur kapabilitas mahasiswa adalah nilai rata-rata ijazah SMA $\left(X_{7}\right)$.

c) Peubah lingkungan dibangun oleh 5 indikator, yang paling dominan mengukur peubah lingkungan adalah situasi tempat tinggal $\left(X_{8}\right)$, dimana dalam perhitungan diperoleh angka sebesar 0.94. Sedangkan indikator terkecil yang mengukur lingkungan adalah sumber biaya hidup/kuliah yang diproleh hasil perhitungan sebesar 0.50. Dengan demikian dapat disimpulkan bawa indikator yang paling dominan mengukur lingkungan mahasiswa adalah situasi tempat tinggal $\left(X_{8}\right)$ mahasiswa tersebut.

d) Berikutnya, peubah prestasi dibangun oleh 3 indikator, dimana yang paling dominan mengukur peubah prestasi adalah indikator IPK $\left(\mathrm{Y}_{1}\right)$ dengan diperoleh nilai sebesar 0.94. Sedangkan indikator yang paling kecil mengukur peubah prestasi adalah nilai $\operatorname{MKDU}\left(\mathrm{Y}_{2}\right)$, dengan diperoleh hasil perhitungan sebesar 0.76. Dengan demikian dapat 
disimpulkan bawa indikator yang paling dominan mengukur prestasi mahasiswa adalah $\operatorname{IPK}\left(\mathrm{Y}_{1}\right)$.

\section{Interpretasi Hasil Dugaan Parameter Koefisien Lintas Model Struktural}

Sebagaimana yang telah dijelaskan sebelumnya bahwa peubah laten eksogen yaitu, motivasi, kapabilitas dan lingkungan berpengaruh nyata terhadap peubah laten endogen yaitu, prestasi. Untuk lebih jelas lagi dalam melihat besar masing-masing pengaruh tersebut, dapat dilihat pada Gambar 6 berikut ini.

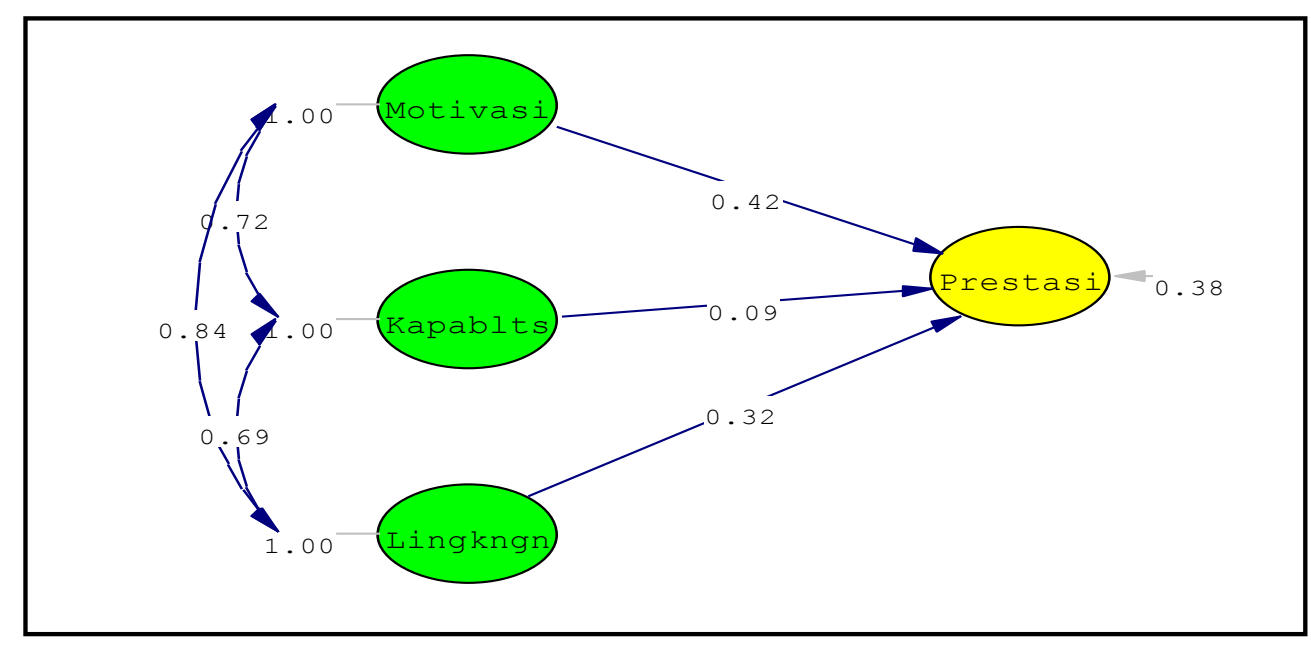

Gambar 6. Hasil Pendugaan Parameter Model Struktural dengan Metode ULS

Berdasarkan Gambar 6 dan nilai T yang disajikan pada Tabel 3 maka dapat dihitung pengaruh langsung, tidak langsung dan total pengaruh dari masing masing peubah laten eksogen yaitu, motivasi, kapabilitas dan lingkungan terhadap peubah laten endogen yaitu, prestasi yang dipaparkan dalam uraian berikut ini.

a) Pengaruh Motivasi Terhadap Prestasi

Berdasarkan nilai-nilai yang ada pada Gambar 6 diketahui bahwa besar koefisien lintas dari motivasi terhadap prestasi sebesar 0.42 dengan arah positif, artinya semakin meningkat motivasi mahasiswa maka akan membuat prestasi mahasiswa meningkat. Besar pengaruh motivasi secara langsung terhadap prestasi sebesar $(0.42)^{2}=0.1764$ 
Perbandingan Antara Unweighted Least Squares (UILS) Dan Partial Least Squares (PLS) Dalam Pemodelan Persamaan Struktural (Studi Kasus Model Analisis Prestasi Belajar Mahasiswa Tahun Pertama Program Studi S1 Matematika Fmipa-Instutut Pertanian Bogor)

atau $17.64 \%$, jadi berdasarkan hasil penelitian diketahui bahwa $17.64 \%$ peningkatan yang terjadi pada prestasi mahasiswa secara langsung disebabkan oleh adanya peningkatan pada motivasi. Sementara secara tidak langsung pengaruh motivasi terhadap prestasi karena hubungannya dengan kapabilitas dan lingkungan sebesar $(0.42 \times 0.72 \times 0.09)+(0.42 \times 0.84 \times 0.32)=0.1401$ atau $14.01 \%$. Jadi secara total pengaruh motivasi terhadap prestasi sebesar $31.65 \%$.

b) Pengaruh Kapabilitas Terhadap Prestasi

Berdasarkan nilai-nilai yang ada pada Gambar 6diketahui bahwa besar koefisien lintas dari kapabilitas terhadap prestasi sebesar 0.09 dengan arah positif, artinya semakin meningkat kapabilitas mahasiswa maka akan membuat prestasi mahasiswa meningkat. Besar pengaruh kapabilitas secara langsung terhadap prestasi sebesar $(0.09)^{2}=0.0081$ atau $0.81 \%$, jadi berdasarkan hasil penelitian diketahui bahwa $0.81 \%$ peningkatan yang terjadi pada prestasi mahasiswa secara langsung disebabkan oleh adanya peningkatan pada kapabilitas. Sementara secara tidak langsung pengaruh kapabilitas terhadap prestasi karena hubungannya dengan motivasi dan lingkungan sebesar $(0.09 \times 0.72 \times$ $0.42)+(0.09 \times 0.69 \times 0.32)=0.0471$ atau $4.71 \%$. Jadi secara total pengaruh kapabilitas terhadap prestasi sebesar $5.52 \%$.

c) Pengaruh Lingkungan Terhadap Prestasi

Berdasarkan nilai-nilai yang ada pada Gambar 6 diketahui bahwa besar koefisien lintas dari lingkungan terhadap prestasi sebesar 0.32 dengan arah positif, artinya semakin meningkat lingkungan mahasiswa maka akan membuat prestasi mahasiswa meningkat. Besar pengaruh lingkungan secara langsung terhadap prestasi sebesar $(0.32)^{2}=0.1024$ atau $10.24 \%$, jadi berdasarkan hasil penelitian diketahui bahwa $10.24 \%$ peningkatan yang terjadi pada prestasi mahasiswa secara langsung disebabkan oleh adanya peningkatan pada lingkungan. Sementara secara tidak langsung pengaruh lingkungan terhadap 
prestasi karena hubungannya dengan motivasi dan kapabilitas sebesar $(0.32 \times 0.84 \times 0.42)+(0.32 \times 0.69 \times 0.09)=0.1428$ atau $14.28 \%$. Jadi secara total pengaruh lingkungan terhadap prestasi sebesar $24.52 \%$.

Adapun formulasi persamaan prestasi mahasiswa adalah sebagai berikut : Prestasi $=0.42 *$ Motivasi $+0.09 *$ Kapabilitas $+0.32 *$ Lingkungan + 0.38 , dengan $R^{2}=0.62$. Hal ini memberikan arti bahwa keragaman prestasi dapat dijelaskan oleh keragaman motivasi, kapabilitas dan lingkungan sebesar $62 \%$. Berdasarkan hasil perhitungan terlihat besarnya pengaruh masing-masing peubah laten eksogen yaitu, motivasi, kapabilitas dan lingkungan terhadap peubah laten endogen yaitu, prestasi. Motivasi memberikan pengaruh yang paling besar daripada pengaruh kapabilitas dan lingkungan. Hal ini dapat diterima karena menurut Sumandi Suryabrata dalam Djaali (2006) motivasi adalah keadaan yang terdapat dalam diri seseorang yang medorongnya untuk melakukan aktivitas tertentu guna pencapaian suatu tujuan. Sementara itu Gates et al dalam Djaali (2006) mengemukakan bahwa motivasi adalah suatu kondisi fisiologis dan psikologis yang terdapat dalam diri seseorang yang mengatur tindakannya dengan cara tertentu. Sedangkan kapabilitas memberikan pengaruh terkecil terhadap prestasi. Hal ini bisa disebabkan : i) prestasi mahasiswa ketika di SMA relatif seragam, ii) tidak ada hubungan yang linear antara prestasi di SMA dengan Prestasi di IPB. Misalkan seseorang yang memiliki NEM yang tinggi di SMA namun memiliki prestasi yang rendah di IPB, demikian juga sebaliknya.

\section{Kesimpulan}

Berdasarkan uraian di atas, dapat disimpulkan bahwa:

1. Hasil pendugaan parameter MPS dengan menggunakan metode ULS dan PLS menunjukkan bahwa seluruh indikator signifikan dan reliabel dalam mengukur peubah latennya. Sedangkan berdasarkan kriteria uji 
Perbandingan Antara Unweighted Least Squares (UILS) Dan Partial Least Squares (PLS) Dalam Pemodelan Persamaan Struktural (Studi Kasus Model Analisis Prestasi Belajar Mahasiswa Tahun Pertama Program Studi S1 Matematika Fmipa-Instutut Pertanian Bogor)

kelayakan model kedua metode tersebut layak dalam mengepas data empirik.

2. Perbandingan hasil pendugaan parameter koefisien lintas model pengukuran, koefisien lintas model struktural, nilai error model pengukuran dan tingkat keragaman $\left(R^{2}\right)$ yang dihasilkan metode ULS dan PLS memperlihatkan:

a) Nilai koefisien lintas model pengukuran yang dihasilkan metode ULS secara umum lebih besar daripada nilai koefisien lintas model pengukuran yang dihasilkan metode PLS .

b) Nilai koefisien lintas model struktural yang dihasilkan metode ULS lebih besar daripada nilai koefisien lintas model struktural yang dihasilkan metode PLS.

c) Nilai error model pengukuran yang dihasilkan metode ULS lebih kecil daripada nilai error model pengukuran yang dihasilkan metode PLS.

e) Tingkat keragaman $\left(R^{2}\right)$ yang dihasilkan metode ULS lebih besar daripada yang dihasilkan metode PLS.

3. Hasil dugaan parameter Model Analisis Prestasi Belajar Mahasiswa Tahun Pertama Program Studi S1 Matematika FMIPA-IPB yang dihasilkan metode ULS memperlihatkan:

a) Peningkatan prestasi belajar mahasiswa dipengaruhi oleh motivasi, kapabilitas dan lingkungan.

b) Indikator yang paling dominan dalam mengukur peubah laten motivasi, kapabilitas, lingkungan dan prestasi berturut-turut adalah cara belajar $\left(X_{6}\right)$, nilai rata-rata ijazah $\operatorname{SMA}\left(X_{7}\right)$, situasi tempat tinggal $\left(\mathrm{X}_{8}\right)$ dan indeks prestasi kumulatif atau IPK $\left(\mathrm{Y}_{1}\right)$.

\section{Daftar Pustaka}

Bollen, K.A. 1989. Structural Equation With Latent Variables. New York : John Wiley \& Sons. 
Chin, W.W., Marcolin, B.L. and Newsted, P.R, 1996. A Partial Least Squares Latent Variable Modelling Approach for Measuring Interaction Effects : Results From A Monte Carlo Simulation Study and Voice Mail Emotion / Adoption Study. http://discnt.cba.uh.edu/chin/icis96.pdf

Chin, W.W., 1998. Issues and Opinion on Structural Equation Modeling. MIS Quarterly. http://www.misq.org/archivist/vol/no22/issuel/vol22nlcomntry.ht $\underline{\mathrm{ml}}$

Chin, W.W., 2000. Partial Least Squares for Researcher : An Overview and Prosentation of Recent Advances Using The PLS Approach. http://disc-nt.cba.uh.edu/chin/indx.html

Djaali, H, 2006. Psikologi Pendidikan. Bumi Aksara, Jakarta.

Hair J.F., R.E. Anderson, R.L Tatham \& W.C. Black. 1998. Multivariate Data Analysis : With Reading. Fourth Edition. New Jersey: Prentice Hall.

Jöreskog, K.G. \& D. Sorbom. 1999. Lisrel 8 New Statistical Features. Scientific Software International.

Sellin, N.,1991. Partial Least Squares Modeling in Research on Educational Achievent. http://www.waxmann.com/fs/sellin.pdf

Sharma, S. 1996. Applied Multivariate Techniques. John Wiley \& Sons, New York.

Tan, W.G., Chan, T. and Gable, G.G, 1999. A Structural Model of Software Maintainer Effectiveness. Proc. $10^{\text {th }}$ Australian Confrence on Information Systems.

http://www.fit.gut.edu.au/infoSys/ism/paper/WTa99-1.pdf

\section{Muhammad Amin Paris}

IAIN Antasari

E-mail: aminparis06@yahoo.com 